\title{
Predation by Atlantic herring, sprat, and sandeels on herring larvae in large enclosures
}

\author{
Lee A. Fuiman ${ }^{1 *}$, John C. Gamble ${ }^{2}$ \\ ${ }^{1}$ Dunstaffnage Marine Research Laboratory, PO Box 3, Oban, Argyll PA34 4AD, Scotland \\ ${ }^{2}$ Department of Agriculture and Fisheries for Scotland, Marine Laboratory, Aberdeen AB9 8BD, Scotland
}

\begin{abstract}
We conducted a predation experiment in $15.5 \mathrm{~m}^{3}$ in situ enclosures to estimate the predation potential of various juvenile and adult fishes on larval Atlantic herring Clupea harengus. Predators were herring, sprat Sprattus sprattus, and sandeels Hyperoplus lanceolatus and Ammodytes tobianus. Herring consumed significantly fewer larvae in $24 \mathrm{~h}$ with less variability in the results than the other predators. Mean instantaneous daily mortality rate for herring was $0.001\left(0.1 \% \mathrm{~d}^{-1}\right)$ whereas it was $0.392\left(32 \% \mathrm{~d}^{-1}\right)$ for all the other predators. These values are 2.3 to 3.5 times those obtained in previous studies for jellyfish predators in enclosures. They are also greater than field estimates of natural mortality for herring larvae of comparable size, suggesting that encounters between herring larvae and larger fishes are rarer in the sea than in our experiment.
\end{abstract}

\section{INTRODUCTION}

Fish larvae are the prey of a wide variety of vertebrate and invertebrate prodators in the sea. Although various types of invertebrates may sometimes be important predators (Lillelund \& Lasker 1971. Theilacker \& Lasker 1974, von Westernhagen \& Rosenthal 1976, Möller 1984, Purcell et al. 1987), fishes probably exert the greatest predation on fish larvae because of their variety, number, size, foraging speed, and voracity. Estimating the mortality imposed by larger fishes on a population of larvae at sea is difficult because of the imprecisions of sampling, high rates of digestion, and the difficulty of quantifying alternative sources of mortality, principally starvation $\left(O^{\prime}\right.$ Connell 1980).

Experimental methods offer the control necessary to avoid the problems inherent in field-based estimates of mortality. However, laboratory experiments may have substantially different environmental characteristics than the sea and the small size of the containers may bias mortality estimates by forcing unusually high encounter rates between predator and prey (de Lafontaine \& Leggett 1987b). Large enclosures (mesocosms) possess nearly natural physical characteristics while

\footnotetext{
- Present address: Marine Science Institute, University of Texas at Austin, Port Aransas, Texas 78373, USA
}

offering more space to predator and prey than could be accomodated in the laboratory (de Lafontaine \& Leggett $1987 \mathrm{a}$ ). To date, enclosures have had only limited use in larval fish predation studies (Frank \& Leggett 1982, Øiestad 1985, de Latontaine 1986, de Lafontainc \& Leggett 1987a, b, Gamble \& Fuiman 1987).

We designed the following investigation to provide a broad estimate of the potential impact of piscine predators on a population of herring larvae. At the same time, we compared the predatory capability of different sizes and species of fish.

\section{METHODS}

Predators and prey. We chose Atlantic herring Clupea harengus L. as prey and one of the predators for this study. The other predators were sprat Sprattus sprattus (L.) and sandeels Ammodytes tobianus L. and Hyperoplus lanceolatus (Lesauvage). These predators coincide with, and probably prey on, herring larvae in the sea (Rankine \& Morrison unpubl.). Larvae came from autumn-spawning adults collected on Aberdeen Bank, northeastern Scotland. Gonads were collected on 21 August 1987 and eggs were fertilized in Aberdeen within $24 \mathrm{~h}$, then incubated at $7^{\circ} \mathrm{C}$, as described by Gamble et al. (1985). Developing eggs were transported to rearing facilities at Loch Ewe, northwestern 
Scotland, on 27 August and maintained at $7{ }^{\circ} \mathrm{C}$. Eggs hatched on 6 September except for one lot which hatched $3 \mathrm{~d}$ later. The temperature was raised to $12^{\circ} \mathrm{C}$ over a period of $24 \mathrm{~h}$ on 7 September to bring larvae up to ambient seawater levels. Larvae were fed daily a mixture of brine shrimp (Artemia sp.) nauplii and rotifers Brachionus plicatilis.

Herring and sprat to be used as predators were collected in Dunstaffnage Bay, near Oban, on the western coast of Scotland, in mid-August 1986 (herring) and 1987 (sprat), held at the Dunstaffnage Marine Research Laboratory for about $2 \mathrm{wk}$, then transported to holding facilities at Loch Ewe. Sandeels were collected in Loch Ewe in 1987. The large sandeels Ammodytes tobianus were mature adults collected near Mellon Charles on 25 August. The small ones Hyperoplus lanceolatus were juveniles caught in Firemore Bay on 11 September. Additional details of the rearing of larvae and the care of predators are given by Gamble \& Fuiman (1987).

Experimental design. Our experiment compared 4 types of predators, each with 8 replicates. The predators represented 2 sizes of fishes from 2 families: Clupeidae and Ammodytidae. There was a 3-fold difference in total length of the clupeids; herring averaged $183 \mathrm{~mm}$ and sprat averaged $63 \mathrm{~mm}$. The lengths of the sandeels differed by a factor of 1.7 (155 and 90 mm; Table 1).

The location, design of experimental facilities, and procedures for conducting the experiment were

Table 1. Characteristics of larvae and predators. Lengths (measured live) and weights of larvae are given as mean and standard deriation (SD) of 20 observations. Lengths are given for each predator used, with mean and SD in parentheses

\begin{tabular}{|lcccc|}
\hline Item & \multicolumn{4}{c|}{ Trial } \\
& 1 & 2 & 3 & 4 \\
\hline Herring larvae & & & & \\
Age posthatching (d) & 8 & 11 & 14 & 14 \\
Standard length $(\mathrm{mm})$ & 8.6 & 9.6 & 9.6 & 10.1 \\
& $(0.6)$ & $10.6)$ & $(0.8)$ & $10.8)$ \\
Dry weight $(\mu \mathrm{g})$ & 84 & 116 & 135 & 171 \\
& $(17)$ & $(16)$ & $(37)$ & $(51)$ \\
Predator total length (mm) & & & & \\
Herring & 178 & 176 & 193 & 181 \\
$(183.0 ; 5.5)$ & 181 & 188 & 183 & 184 \\
Sprat & 68 & 58 & 66 & 66 \\
$(62.9 ; 4.3)$ & 67 & 58 & 59 & 61 \\
Large sandeel & 155 & 167 & 150 & 147 \\
$(155.4 ; 7.9)$ & 157 & 167 & 151 & 149 \\
Small sandeel & 89 & 80 & 96 & 90 \\
$(89.9 ; 6.6)$ & 96 & 88 & 98 & 82 \\
\hline
\end{tabular}

described by Gamble \& Fuiman (1987). Important details and modifications are given here. There were 8 enclosures arranged in 2 rows of 4 , suspended from a raft so that the upper $0.5 \mathrm{~m}$ of each enclosure was above the water surface. The upper $5 \mathrm{~m}$ of each enclosure was a column $2 \mathrm{~m}$ in diameter. Between 5 and $6.5 \mathrm{~m}$ from the top the enclosures tapered to a $20 \mathrm{~cm}$ drain hole. They were made of opaque, black PVC sheeting ( $0.54 \mathrm{~mm}$ thick) and enclosed $15.5 \mathrm{~m}^{3}$ of water each. The opaque material was necessary to prevent anomalous results caused by sunlight shining through the enclosures (Gamble \& Fuiman 1987). The black material caused lower light levels within the enclosures, ranging from 7500 lux at the surface to 170 lux at the bottom (as compared with 12800 to 1580 lux at the same depths outside the enclosures), but still greater than the 0.1 lux necessary for normal feeding activity of the predators (Blaxter 1970). Light levels were greater than 0.1 lux at mid-depth in the enciosures for about 13.75 h daily.

Before beginning the experiment, we established the accuracy of our methods for counting out and recovering larvae with 8 control enclosures handled in the same way as the experimental ones except that each contained 200 or 400 larvae and no predators.

In each of 4 experimental trials $(13,16,19,22 \mathrm{Sep}-$ tember) we randomly assigned 2 enclosures to each predator type. We used 400 larvae and a single predator per enclosure. Larvae were taken from the earlier hatch for Trials 1 through 3 and the later hatch for Trial 4. On the day prior to each experiment, enclosures were filled with water filtered through a 40 um mesh plankton net. At the same time, 400 larvae were pipetted individually into each of 9 acrylic tubes. These were sealed and transported to the enclosures, then the larvae were released into the enclosures by 16:30 $\mathrm{h}$ (GMT) on the same day. The remaining tube was returned to the rearing facilities and left undisturbed until the time of the experiment when dead larvae were counted and measurements of length and dry weight were made.

Since predator satiation can seriously affect predation rate (Hourston et al. 1981, Gamble \& Fuiman 1987), we attempted to use predators that were all in the same state of hunger by not feeding them during the $48 \mathrm{~h}$ preceding an experiment. Larvae were not fed after they were released into the enclosures. At 09:00 h on the morning after larvae were released, a single predator was added to each enclosure. Predation was terminated $24 \mathrm{~h}$ later by adding quinaldine (2-methylquinoline, using acetone as a carrier, 1:4) to a final concentration of $10 \mathrm{ppm}$. The enclosures were drained through a $250 \mu \mathrm{m}$ mesh bag and their contents fixed in $5 \%$ formalin. The number of larvae remaining in each enclosure was determined within 24 h of the termina- 
tion of a trial. Feeding was verified by examining the gut contents of each predator. Sea temperature during the experiment was 11.7 to $11.9^{\circ} \mathrm{C}$ at the surface and at $4 \mathrm{~m}$.

We expected foraging speed to be related to the size of the predator. Thus differences in predation rate might be explained by foraging speed. We measured foraging speed during Trial 2 by placing a single predator in a black, $2.5 \mathrm{~m}$ circular tank (located outdoors at the laboratory site) with a sheet of retroreflective material (Scotchlite) on the bottom marked with a $20 \mathrm{~cm}$ grid. The predator's behaviour was recorded on video tape ( 50 fields $\mathrm{s}^{-1}$ ) after a $30 \mathrm{~min}$ period of acclimation. This procedure was repeated for each predator species. Foraging speed was estimated by digitising several swimming path segments (totalling at least 300 s) of the predator from the video tape, computing path length and duration for each segment, then calculating a mean weighted by the duration of the path segment. The sandeels did not swim in the tank, so we obtained no measurements of their foraging speed.

Statistical analyses were performed on the number of larvae remaining in the enclosures, using the SYSTAT statistical package on a microcomputer (Wilkinson 1986). Statistical tests used are descirbed in either Snedecor \& Cochran (1967) or Conover (1980).

\section{RESULTS}

\section{Statistical nature of daia}

The percentage of larvae recovered from control enclosures ranged from 95.0 to 100.5 , averaging 98.4 $( \pm 2.14 \mathrm{SD})$. This value includes those larvae that died while in the enclosures since it was not possible to distinguish with certainty such larvae from those that survived until fixation. The mean mortality in the 4 samples of larvae transported to the field and back to the laboratory was 6.8 ( \pm 3.0$)$ larvae $(1.7 \%)$. This low value is probably an overestimate because these larvae were transported twice the distance and were more confined than those in the enclosures. During the $9 \mathrm{~d}$ spanned by the trials the larvae grew approximately $1.5 \mathrm{~mm}$ in length and $87 \mu \mathrm{g}$ in dry weight (Table 1).

Previous predation studies showed that the number of larvae recovered from enclosures may not be normally distributed, thus violating the assumptions of parametric statistical tests (Gamble \& Fuiman 1987). To test for normality we combined the results for different predators (Table 2) by normalizing each observation (subtracting the mean and dividing by the standard deviation for its predator type). A Lilliefors test showed the overall distribution to be normally distributed $(p=0.360)$.
Table 2. Number of larvae remaining in each enclosure corresponding with the predators in Table 1. Superscripts indicate nature of gut contents (-, no remains of larvae; b, recognizable bodies of larvae; $r$, digested remains of larvae, mostly retinal material ${ }_{i}$ ? uncertain result)

\begin{tabular}{|lccccc|}
\hline Predator & \multicolumn{5}{c|}{ Larvae remaining (out of 400) } \\
& 1 & 2 & 3 & 4 & $\begin{array}{c}\text { Mean } \\
\text { (SD) }\end{array}$ \\
\hline Herring & & & & & \\
& $384^{\mathrm{b}}$ & $375^{\mathrm{b}}$ & $383^{\mathrm{b}, 3 \mathrm{r}}$ & $392^{-}$ & 386.5 \\
Sprat & $388^{\mathrm{r}}$ & $366^{\mathrm{b}}$ & $395^{\mathrm{b}}$ & $409^{\mathrm{b}}$ & $(13.0)$ \\
& $15^{\mathrm{r}}$ & $307^{-}$ & $294^{\mathrm{r}}$ & $43^{\mathrm{b}, \mathrm{r}}$ & 223.0 \\
Large sandeel & $222^{\mathrm{r}}$ & $343^{\mathrm{b}, \mathrm{r}}$ & $294^{\mathrm{r}}$ & $266^{\mathrm{rr}}$ & $(124.8)$ \\
& $274^{\mathrm{r}}$ & $358^{-}$ & $381^{-}$ & $102^{\mathrm{b}, \mathrm{r}}$ & 252.4 \\
Small sandeel & $159^{\mathrm{b} . \mathrm{r}}$ & $378^{-}$ & $286^{-}$ & $81^{\mathrm{rr}}$ & $(122.9)$ \\
& $383^{-}$ & $274^{-}$ & $281^{\mathrm{r}}$ & $213^{\mathrm{r}}$ & 309.0 \\
Mean & $370^{-}$ & $330^{\mathrm{b}}$ & $382^{\mathrm{b}, \mathrm{r}}$ & $239^{\mathrm{b}}$ & $(66.6)$ \\
(SD) & 125.6 & 58.6 & 63.0 & 181.9 & 292.7 \\
& $(135.9)$ & $(36.3)$ & $(51.9)$ & $(137.5)$ & $(109.5)$ \\
\hline
\end{tabular}

We tested for differences in results among the trials because each was performed on a different day with different meteorological conditions and different sizes of larvae. Although a 1-way ANOVA showed no effect $(p=0.069)$, the assumption of homogeneous variances was violated ( $p=0.002$, Bartlett's test). The non-parametric Krustal-Wallis ANOVA also indicated that there was no difference between trials $(p=0.322)$.

\section{Effect of predator size and species}

All predator types fed on herring larvae as was evident by the reduction of larvae in each enclosure and their presence in the guts of most predators (Table 2). Further, the state of digestion of most larvae (usually only traces of melanin from retinae in the hindgut) indicated that feeding had occurred for several hours prior to termination, and possibly before nightfall (13 h previously). Only a few predators contained wellformed larvae, but these were partly digested and located in the stomach (not the esophagus) and therefore probably were not ingested while the enclosure was being emptied.

The mean number of larvae remaining out of 400 was 292.7 per enclosure, with the greatest predation rate achieved by a sprat (15 larvae remaining). A 1-way parametric ANOVA showed a significant $(p=0.009)$ difference between predators but, again, the variances were not equal $(p<0.001)$. The Kruskal-Wallis ANOVA also gave a significant result $(p=0.001)$. It was obvious that the differences identified by the parametric tests were due, at least in part, to the small 
variance and large mean for the data from the herring (Table 2; Fig. 1). With these data removed the variances for the 3 remaining predator types were equal $(p=0.244)$ and there were no differences in their means $(p=0.292)$.

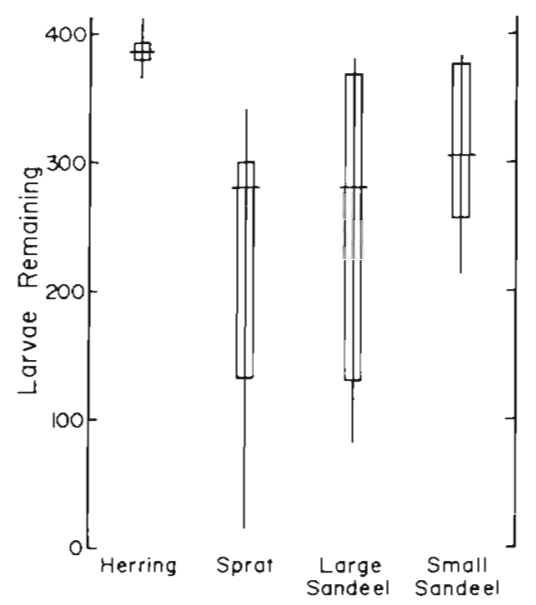

Fig. 1. Comparison of predators. For each predator, vertical line presents range of observations, box encloses interquartile range, and median is denoted by a horizontal line $(n=8)$

The effect of predator size on predation rate was more evident in clupeids than in sandeels. As expected, large sandeels ate more larvae on average than small sandeels. But the regression of number of larvae remaining on predator length for sandeels was not significant $(p=0.509)$. Unexpectedly, large clupeids (herring) ate fewer larvae than did small clupeids (sprat). This result was not explained by differences in foraging speed. Herring swam at an average speed of $8.4 \mathrm{~cm} \mathrm{~s}^{-1}( \pm 4.1)$ and sprat swam at $7.2 \mathrm{~cm} \mathrm{~s}^{-1}( \pm 2.8)$. Herring spent most of the time near the sides of the tank, whereas sprat swam in the central area.

\section{DISCUSSION}

The single measured variable obtained from these experiments is the number of larvae remaining (survivorship). It is dependent upon 3 components: (1) encounter rate, (2) the probability that a predator will attack an encountered prey, and (3) the probability of capture, given an attack. Each of these components may be affected by other factors resulting in a change in survivorship. We expected size- or species-related differences in foraging speeds of predators and that these would act on survivorship through encounter rate. We also expected, but could not predict, interspecific differences in voracity (including prey preference) which would affect the probability of an attack.

There was a small difference in the foraging speed of small and large clupeids. However, the faster herring consumed fewer larvae than the sprat. Size-related differences in foraging speed may occur in sandeels, but we were unable to obtain such measurements. If they do exist, their effect on predation rate is masked by the variance in the latter and the possibility of differences between the 2 species that affect their proclivity to consume herring larvae.

We suspect that the low predation rate of herring resulted from a low probability that they would attack nearby herring larvae, rather than a difference in rates of encounter or capture success. This may have resulted from their captivity. The herring had been confined and fed an artificial diet for $1 \mathrm{yr}$. The sandeels and sprat received this treatment for less than $5 \mathrm{wk}$. With this possibility in mind, we moved a large number of herring to a separate tank and fed them only natural zooplankton for $10 \mathrm{~d}$ prior to Trial 4 . These predators were used in that trial and showed no more predation than the herring in previous trials. Although not conclusive, this test plus the fact that the large herring fed at least a little indicates that the long period of feeding on an artificial diet may not be responsible for their low predation rate.

Alternatively, there may be an inherent difference between herring and other species, explained through arguments based in optimal foraging theory or evolutionary ecology and cannibalism. Or perhaps the herring were not as motivated to feed as the other predator types by the $48 \mathrm{~h}$ of food deprivation preceding each trial. They probably had larger stores of energy than the others, built up over their year of captivity.

\section{Predation mortality}

On average our predators each consumed 107.3 $( \pm 109.47, N=32)$ larvae $d^{-1}$. This is equivalent to an instantaneous daily mortality rate $(Z)$ of 0.279 , using the formula:

$$
Z=\ln \left(N_{\mathrm{a}} / N_{\mathrm{i}}\right)-\ln \left(N_{\mathrm{i}} / N_{\mathrm{c}}\right)
$$

modified slightly from de Lafontaine \& Leggett (1987b) to accomodate handling mortality. Here $N_{\mathrm{a}}=$ number of larvae available to the predator (i.e. number stocked into each enclosure, $N_{i}$, less handling mortality; $400-6.8) ; N_{c}(=393.6)$ and $N_{\mathrm{f}}=$ mean number remaining in the control enclosures and in those with predators, respectively. We used mean values for $N$, rather than averaging $Z$ values calculated for each enclosure, because the latter were not normally distributed. The $95 \%$ confidence limits for the above estimate are 0.152 and 0.424 . This translates into mortality rates due to predation by larger fishes of 14 to $35 \% \mathrm{~d}^{-1}$, averaging $24 \% \mathrm{~d}^{-1}$. When the data for herring are omitted, the

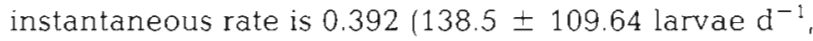


$N=24$ ) with confidence limits of 0.229 and 0.587 , or 20 to $44 \% \mathrm{~d}^{-1}$, averaging $32 \% \mathrm{~d}^{-1}$.

Field estimates of instantaneous mortality rates for populations of Atlantic herring larvae are also highly variable. From Heath \& MacLachlan (1987), Munk et al. (1986), and McGurk's (1986) summary, the mean reported rate is $0.12 \mathrm{~d}^{-1}$, with a minimum of 0.02 (from off the Outer Hebrides; Heath \& MacLachlan 1987) and a maximum of 0.46 (Norway; Dragesund \& Nakken 1971). Our mean values, 0.279 and 0.392 , fall within the extremes of the field estimates but are well above the mean, despite the fact that field-based estimates include all sources of mortality, not just predation. The reasons for the deviation lie in either intrinsic bias in either or both of the estimates or a higher encounter rate in the enclosures, which is probably caused by artificiality of the experimental conditions (e.g. prey density or predator density).

In our experiments the initial density of larvae was $25.8 \mathrm{~m}^{-3}$. This value is well within the range of mean maximum field estimates of 21 to 59 larvae $\mathrm{m}^{-3}$ obtained for recently hatched herring larvae occurring off the west, north, and east coasts of Scotland (ICES herring larval database 1972-1985, P. Rankine pers. comm.; Munk et al. 1986, Heath \& MacLachlan 1987). Further, de Lafontaine \& Leggett (1987b) found that initial prey density did not affect estimates of $Z$, using jellyfish as predators in enclosures. Our unpublished data support this observations. Instantaneous mortality rates we determined from experiments using only herring as predators were the same with 12.9 larvae $\mathrm{m}^{-3}$ as with 25.8 larvae $\mathrm{m}^{-3}$.

An important difference between our experimental estimates of $Z$ and field estimates is that the former represent daily mortality per predator, rather than total daily mortality of the population. The difference between the 2 estimates may indicate that juvenile and adult fishes (predators) are more sparsely distributed in the areas occupied by young herring larvae (i.e. their natural density is much less than $1 / 15.5 \mathrm{~m}^{3}$ ).

Nevertheless, fishes have a potentially far greater impact on populations of larvae than other types of predators. Mean instantaneous daily mortality rates for larvae exposed to jellyfish predators in large enclosures range from 0.015 to 0.12 (Gamble \& Houde 1984, Øiestad 1985, de Lafontaine \& Leggett 1987b). Our mean values for 3 or 4 species of predators are 2.3 and 3.5 times the highest mean for jellyfish predators. The difference is amplified further when one considers that fishes generally are visual predators and that jellyfish are not. In our experiments there were only about 13.75 h of visual feeding per day, based on the 0.1 lux threshold defined by Blaxter (1970). The length of the feeding day, and hence daily mortality rates, changes substantially during the year at this latitude.
Maximum predation rates calculated for each type of predator (Table 3 ) or for the 3 enclosures having fewest larvae remaining, $Z=1.6$ to 3.3 or 79 to $96 \%$ consumed $\mathrm{d}^{-1}$, underscore the enormous predation potential of juvenile and adult fishes on fish larvae. It seems unlikely to us that the $15.5 \mathrm{~m}^{3}$ enclosures were small enough to inflate our estimates of mortality rate substantially (de Lafontaine \& Leggett 1987b), but this needs verification.

Table 3. Mean and maximum instantaneous daily mortality rates (Z). Values were computed from means and maxima given in Table 2 using the formula given in the text

\begin{tabular}{|lccccc|}
\hline & Herring & Sprat & $\begin{array}{c}\text { Large } \\
\text { sandeel }\end{array}$ & $\begin{array}{c}\text { Small } \\
\text { sandeel }\end{array}$ & Overall \\
\hline Mean & 0.001 & 0.551 & 0.427 & 0.225 & 0.279 \\
Maximum & 0.056 & 3.250 & 1.564 & 0.597 & \\
\hline
\end{tabular}

Future research

The predators used in this experiment are schooling fishes and as a school probably have enhanced predatory capabilities when compared with solitary individuals (Pitcher 1986). In recognition of this we used 2 herring per enclosure in our previous experimental series (Gamble \& Fuiman 1987), but the results obtained were too variable to be rigorously interpreted. In particular, it was not possible to resolve whether we were measuring the feeding of one or both individuais in a single trial. The current experiment, with single predators, solved the statistical problem but did not address the effect of schooling. Even if the $15.5 \mathrm{~m}^{3}$ enclosures were large enough for single individuals, we would certainly need much larger enclosures to study schools of predators which have higher foraging rates.

An alternative approach would be to compare normally solitary species with individuals of schooling ones. This was our intention for the present study but we were unable to obtain suitably sized predators (0-group gadoids) during the time when herring larvae were available. Clearly, schooling, together with the effect of enclosure size, is in need of further investigation.

Acknowledgements. We thank Duncan Seaton for collecting the herring gonads, John Dunn for designing and constructing the enclosure system, and Duncan Seaton and Philip Maclachlan for assisting during the experiment. Yves de Lafontaine kindly provided a prepublication copy of his work. We thank John Blaxter, Bob Batty, and John Davies for their review of the manuscript. This material is based upon work supported, in part, by the (US) National Science Foundation, under Grant BSR-8503058 awarded in 1985 to L.A.F. 


\section{LITERATURE CITED}

Blaxter, J. H. S. (1970). Light. In: Kinne, O. (ed.) Marine ecology, Vol. I, Environmental factors, Part 1. Wiley-Interscience, London, p. 213-320

Conover, W. J. (1980). Practical nonparametric statistics. John Wiley and Sons, New York

de Lafontaine, $Y$ (1986). Experimental evaluation of the impact of macrozooplankton predation on mortality in larval capelin (Mallotus villosus Müller). Ph. D. thesis, McGill University, Montreal

de Lafontaine, Y., Leggett, W. C. (1987a). Evaluation of in situ enclosures for larval fish studies. Can. J. Fish. aquat. Sci. 44: $54-65$

de Lafontaine, Y., Leggett, W. C. (1987b). Effect of container size on estimates of mortality and predation rates in experiments with macrozooplankton and larval fish. Can. J. Fish aquat. Sci. 44: 1534-1543

Dragesund, O., Nakken, O. (1971). Mortality of herring during the early larval stage in 1967. Rapp. P.-v. Réun. Cons. int. Explor. Mer 164: 142-146

Frank, K. T., Leggett, W. C. (1982). Coastal water mass replacement: its effect on zooplankton dynamics and the predator-prey complex associated with larval capelin (Mallotus villosus). Can. J. Fish. aquat. Sci. 39: 991-1003

Gamble, J. C., Fuiman, L. A. (1987). Evaluation of in situ enclosures during a study of the importance of starvation to the vulnerability of herring larvae to a piscine predator. J. exp. mar. Biol. Ecol. 113: 91-103

Gamble, J. C., Houde, E. D. (1984). Growth, mortality and feeding of cod (Gadus morhua L.) larvae in enclosed water columns and in laboratory tanks. Flødevigen Rapp. 1: $123-143$

Gamble, J. C., MacLachlan, P., Seaton, D. D. (1985). Comparative growth and development of autumn and spring spawned Atlantic herring larvae reared in large enclosed ecosystems. Mar. Ecol. Prog. Ser. 26: 19-33

Heath, M. R., MacLachlan, P. (1987). Dispersion and mortality of yolk-sac herring (Clupea harengus L.) larvae from a spawning ground to the west of the Outer Hebrides. J. Plankton Res. 9: 613-630
Hourston, A. S., Rosenthal, H., Kerr, S. (1981). Capacity of juvenile Pacific herring (Clupea harengus pallasi) to feed on larvae of their own species. Can. Tech. Rep. Fish. Aquat. Sci. 1044: 1-9

Lillelund, K., Lasker, R. (1971). Laboratory studies of predation by marine copepods on fish larvae. Fish. Bull. U. S. 69 : 655-667

McGurk, M. D. (1986). Natural mortality of marine pelagic fish eggs and larvae: role of spatial patchiness. Mar. Ecol. Prog. Ser. 34: $227-242$

Möller, H. (1984). Reduction of a larval herring population by jellyfish predator. Science 224: 621-622

Munk, P., Christensen, V., Paulsen, H. (1986). Studies of a larval herring (Clupea harengus L.) patch in the Buchan area. II. Growth, mortality and drift of larvae. Dana 6: $11-24$

O'Connell, C. P. (1980). Percentage of starving northern anchovy, Engraulis mordax, larvae in the sea as estimated by histological methods. Fish. Bull. U. S. 78: 475-489.

Øiestad, V. (1985). Predation on fish larvae as a regulatory force, illustrated in mesocosm studies with large groups of larvae. NAFO Sci. Coun. Studies 8: 25-32

Pitcher, T. J. (1986). Functions of shoaling behaviour in teleosts. In: Pitcher, T J. (ed.) The behaviour of teleost fishes. Croom Helm, London, p. 294-337

Purcell, J. E., Siferd, T. D., Marliave, J. B. (1987). Vulnerability of larval herring (Clupea harengus pallasi) to capture by the jellyfish Aquorea victoria. Mar. Biol. 94: 157-162

Snedecor, G. W., Cochran, W. C. (1967). Statistical methods. Iowa State University Press, Ames

Theilacker, G. H., Lasker, R. (1974). Laboratory studies of predation by euphausiid shrimps on fish larvae. In: Blaxter, J. H. S. (ed.) The early life history of fish. SpringerVerlag, Berlin, p. 287-299

von Westernhagen, H., Rosenthal, H. (1976). Predator-prey relationship between pacific herring, Clupea harengus pallasi, larvae and predatory hyperiid amphipod, Hyperoche medusarum. Fish. Bull. U. S. 74: 669-674

Wilkinson, L. (1986). SYSTAT: the system for statistics. SYSTAT Inc., Evanston, Illinois

This article was presented by Dr R. S. Batty; it was accepted for printing on February 9, 1988 